\title{
EVALUATING INNOVATION CAPABILITIES OF REAL ESTATE FIRMS: A COMBINED FUZZY DELPHI AND DEMATEL APPROACH
}

\author{
Anil KUMAR ${ }^{\text {a }}$, Mohamad Amin KAVIANI ${ }^{\text {b }}$, Ashkan HAFEZALKOTOB ${ }^{\text {, }}$, \\ Edmundas Kazimieras ZAVADSKAS c,* \\ a School of Management, BML Munjal University, Gurgaon (Haryana), India \\ ${ }^{b}$ Young Researchers and Elite Club, Shiraz Branch, Islamic Azad University, Shiraz, Iran \\ ${ }^{c}$ Department of Construction Management and Real Estate, Vilnius Gediminas Technical University, \\ Sauletekio al. 11, LT-10223 Vilnius, Lithuania
}

Received 27 January 2017; accepted 4 September 2017

\begin{abstract}
Due to strong competition, numerous technology advancements and the monetary policy of the government, the survival of Indian real estate firms now depends on their capacity to measure their existing innovation capabilities, rebuild them and adopt new ones. The aim of this study is to evaluate the technology and human resources innovation capabilities of Indian real estate firms by applying fuzzy Delphi and DEMATEL techniques. After identifying the innovation capabilities through an extensive literature review, a questionnaire is designed based on fuzzy linguistic scales to manage any vagueness of information received. Data has been collected from experts in the field, with capabilities then finalized by using a fuzzy Delphi method. To establish cause-effect relationships among capabilities, a DEMATEL method is applied to the data collected from a second questionnaire. Analysis of the data divides capabilities into two groups i.e. cause and effect. The results show that innovation management, robustness of product and process design capability, strategic planning and knowledge resources fall in the cause group; these are critical findings given the effect on the other capabilities. The study outcomes can help real estate firms to enhance their capabilities with the proposed model providing guidelines and direction in this regard.
\end{abstract}

KEYWORDS: Technology innovation capabilities; Human resources innovation capabilities; DEMATEL; Fuzzy Delphi; Knowledge resources

SUPPLEMENTARY MATERIAL associated with this article can be found, in the online version, at https://doi.org/10.3846/1648715X.2017.1409291

\section{INTRODUCTION}

The Indian real estate sector is one of the most globally recognized sectors in the country; after agriculture, it is the largest national employer. It is expected that this sector will turn over USD 180 billion by 2020. Housing, retail, hospitality and commercial properties are the four major sub sectors of Indian real estate; among these, the housing sector contributes 5-6\% to the country's Gross Domestic Product. To make this business more transparent, the Real Estate (Regulation and Development) Act 2016 has been passed by the Indian Government. But unpredictable and extremely rapid changes have taken place due to strong market competition, advancements in technology,

* Corresponding author. E-mail: edmundas.zavadskas@vgtu.lt fluctuations in the financial market and changes in consumer demands. The demonetization decision taken by the Indian Government has had an undeniable impact on real estate with those properties being resold seen to be most affected. The affluent and higher priced section of the housing market are affected to a greater degree; hence the costs of the more exclusive and expensive houses are likely to come down by $20-30 \%$ following demonetization.

To cope with the dynamic environment and competition, the Indian real estate business requires unending technological modification and managerial expertise. Therefore, the sector must think about industry enlivenment, an adaptation of innovative technology and managerial response. The real challenge going forward is the constantly fluctuating environment which creates hurdles for 
the developers as well as the investors in the real estate sector. There needs to be a way to establish a durable, healthy and competent Indian real estate sector which can preserve its growth over the coming years. Looking from a long term corrective perspective, it is vital that there should be transparency in the real estate sector to make it sustainable and attractive to investment. Innovation is a necessity not only to help the organization to survive but also to increase a firm's competitiveness in the market place. Real estate firms must rethink their existing innovation capabilities, rebuild them and adapt new ones ready for implementation. This can be achieved by restructuring the business practices of real estate organizations to cope with the pressures of the market. Going forward, real estate firms need to assimilate their human resources innovation capabilities (HIRC) and technological innovation capabilities (TIC) to ensure corporate survival; efforts must be focused on improving organizational systems and the use of existing resources from all departments. These innovation capabilities are viewed as the major factors responsible for reinforcing the competitive spirit of organizations by building up new opportunities for the growing market (Garcia, Calantone 2002; Yang et al. 2015).

Innovation is not only involved with problem solving. There has always been a component related to an upgraded economic scenario and competitive performance when enhancement in technology takes effect. The most important aspect for any organization to consider is to establish how they can develop or assess their capability to build up technology and human resources innovation. This is the focal point of this study with Technological Innovation Capabilities (TICs) and Human Innovation Resources Capabilities (HIRCs) seen as the target concepts. HIRCs are central to an organization when forward planning in technology, knowledge sharing, improvement, process, organization and production (Guan et al. 2006). TICs enable organizations to cope with changing market situations while maintaining levels of customer expectations; this helps in achieving growth in an innovation-driven sector. Improving TICs can reinforce the competitiveness of companies. TICs should be embraced especially by those organizations heavily involved in technology and human resources because they take an assertive role in aiding economic advancements and competitiveness (Shafia et al. 2016); these are usually the leaders of technology innovation within their industry.
In light of the above discussion and an extensive literature review, it is concluded that technological and human innovation capabilities are the most important capabilities for the performance of any organization. This is especially true for the Indian real estate sector, a rising sector with a capacity for growth. But there has been a lack of research into innovation capabilities in Indian real estate firms. As a result, there is inadequate knowledge about the inter-relationships among these innovation capabilities. With this literature gap, the study concentrates on finding the technological innovation capabilities and human resource innovation capabilities of Indian real estate firms by devising an inter-relationship model of these innovation capabilities.

The methodology used to achieve the objectives of this study is also important. Identifying innovation capabilities through a literature review does not fulfil the study aim; we also want to know expert opinions and develop a cause-effect evaluation model i.e. Network Relation Map (NRM) among the capabilities. To integrate expert judgment into the process for finalizing the evaluation capabilities, a fuzzy Delphi method (FDM) is employed. FDM has the potential to reduce the problem of fuzzy human thoughts and low level of accuracy (Ishikawa et al. 1993; Wu 2012; Kumar, Dash 2017b). But in current literature, no research has investigated a Delphi method with fuzzy theory to choose the technological innovation and human resource innovation capabilities for real estate firms; DEMATEL has not previously been used to establish the inter-relationships among the selected capabilities (Wu, Tsai 2012; Kumar, Dash 2016). Decision Making Trial and Evaluation Laboratory (DEMATEL) is based on graph theory and builds an NRM among the evaluated capabilities. Therefore, this is an attempt to fill this literature gap by using integrated Fuzzy Delphi and DEMATEL methods for measuring technological innovation and human resource innovation capabilities in the Indian real estate sector.

The whole study is divided into six parts. The introduction to the study is given in the first part. A literature review is outlined in the second part. In the third part, solution methods are described. Research framework and analysis are discussed in the fourth part. The fifth part gives theoretical and practical implications of the study. Conclusions and future research directions are given in the last part of the paper. 


\section{LITERATURE REVIEW}

The review examines relevant literature on Technological Innovation Capabilities (TIC), Human Resources Innovation Capabilities (HRIC) and applications of MCDM in the real estate sector.

\subsection{Technological Innovation Capabilities (TIC)}

A study of current literature reveals that TIC has received a great deal of attention from researchers during the past three decades. Burgelman et al. (1988) considered TIC as a movement of parts in supporting the organization's framework; this included an impression of the business headway, comprehension of the development change together with the outline and general culture of the firm. Adler and Shenbar (1990) described TIC as the capacity for developing new things, applying legitimate method advancements, making and grasping new advances while responding to unanticipated mechanical changes. In the same year, Cohen and Levinthal (1990) examined the capacity of a firm to estimate new, external information, to adapt it and to apply it to a business model to gain maximum benefit. Thereafter, Lall (1992) stated that TIC is shown by the ability to viably ingest, apply and enhance existing advancements while developing new ones. Leonard-Barton (1992) suggested that the core of TIC is comprised of elements such as skills, specialized frameworks, administration frameworks and the qualities and standards of the firm. Afuah and Bahram (1995) suggested that technological invention involves several contrasts; these were named as new technological facilities, enterprisebased variations and the actions taken by the board of a company. Panda and Ramanathan (1996) concluded that much information was plagiarized from other technological sources; by examining inputs or actions taken by international firms, a sound business plan could be put in place to maximise the benefits of existing and new technology.

Guan and Ma (2003) concluded that TICs are an uncommon resource of a development project. They have distinctive key territories, for example, innovation, generation, process, learning, encounters and association. They considered the roles played by the seven advancement capacity measurements - learning, innovative work (R\&D), fabricating, promoting, authoritative, asset al. otting and procedure arranging - and the three central features of a business - percentage of the market sector, size and profitability development rate - in assessing the performance of several mechanical firms. Burgelman et al. (2004) suggested that TICs are an exhaustive arrangement of qualities of an association that encourages and promotes its mechanical advancement techniques. Woolthuis et al. (2005) demonstrated that most of the problems and disillusionment recognized after an amalgamation are related to fundamental issues: structure, association, cooperation and limit dissatisfactions. Regardless, it is difficult to examine the use and execution of a particular essential segment without suggesting possible outcomes for advancement technique. Akman and Yilmaz (2008) noted that innovation could be seen as a key accomplishment variable in a well engaged, overall economy. The purpose behind their study was to take an overall view of the relations of how a business is presented, progression strategy, innovative capacity and improvement achievement in small and medium-sized businesses in manufacturing countries.

Chang and Lee (2008) examined the impact of learning gathering capacity on hierarchical advancement; their focus was to discover if association between the outer environment or hierarchical society and learning gathering capacity would impact on authoritative development. They utilized a quantitative examination method. The exploration results demonstrated that the capacity to acquire information can indeed influence learning regulatory and specialized advancement. Information extension ability can also influence authoritative development. Moreover, the outside environment and hierarchical society have a critical association with the learning capacity of authoritative development. De Blasio et al. (2015) stated that technological innovation is a key ingredient in building high performance organizations and that robust evaluation of technological innovation capabilities is very important for decision makers. Mortazavi Ravari et al. (2016) evaluated the technology innovation capabilities of several research and technology organizations (RTOs). Organizations with a high status of TIC, beyond their innate ability to provide innovative processes or products, have the ability to tackle any sudden changes and to perform well in unexpected situations (Teece et al. 1997; Zhao et al. 2013; Yang et al. 2015; Gupta, Barua 2016). In Table 1, various technological capabilities with their citations are depicted. 
Table 1. Technological innovation capabilities

\begin{tabular}{|c|c|}
\hline Criteria & Support references \\
\hline $\begin{array}{l}\text { Innovation } \\
\text { management } \\
\text { capability }\end{array}$ & $\begin{array}{l}\text { Burgelman et al. (1988), Adler and Shenbar (1990), Cohen and Levinthal (1990), Damanpour } \\
\text { (1991), Afuah and Bahram (1995), Panda and Ramanathan (1996), Oyelaran-Oyeyinka et al. } \\
\text { (1996), Woolthuis et al. (2005), Wang et al. (2008), Akman and Yilmaz (2008), Zandhessami and } \\
\text { Jalili (2014), De Blasio et al. (2015), Mortazavi Ravari et al. (2016) }\end{array}$ \\
\hline $\begin{array}{l}\text { Collective learning } \\
\text { capability }\end{array}$ & $\begin{array}{l}\text { Wang et al. (2008), Forsman (2011), Lin et al. (2013), Sumrit and Anuntavoranich (2013), Xiaobo } \\
\text { and Sivalogathasan (2013), Zandhessami and Jalili (2014), De Blasio et al. (2015) }\end{array}$ \\
\hline $\begin{array}{l}\text { Technology } \\
\text { commercialization } \\
\text { capability }\end{array}$ & $\begin{array}{l}\text { Burgelman et al. (1988), Woolthuis et al. (2005), Wang et al. (2008), Akman and Yilmaz (2008), } \\
\text { Chang and Lee (2008), Perdomo-Ortiz et al. (2009), De Blasio et al. (2015), Mortazavi Ravari } \\
\text { et al. (2016) }\end{array}$ \\
\hline $\begin{array}{l}\text { Strategic planning } \\
\text { capability }\end{array}$ & $\begin{array}{l}\text { Burgelman et al. (1988), Adler and Shenbar (1990), Cohen and Levinthal (1990), Damanpour } \\
\text { (1991), Lal (1992), Afuah and Bahram (1995), Panda and Ramanathan (1996), Lin et al. (2010), } \\
\text { Lin et al. (2013), Sumrit and Anuntavoranich (2013), Zandhessami and Jalili (2014), De Blasio } \\
\text { et al. (2015), Mortazavi Ravari et al. (2016) }\end{array}$ \\
\hline $\begin{array}{l}\text { Innovation decision } \\
\text { capabilities }\end{array}$ & $\begin{array}{l}\text { Woolthuis et al. (2005), Akman and Yilmaz (2008), Chang and Lee (2008), Perdomo-Ortiz et al. } \\
\text { (2009), Lin et al. (2010), Lin et al. (2013), Xiaobo and Sivalogathasan (2013), Serrano García and } \\
\text { Robledo Velásquez (2013) }\end{array}$ \\
\hline Marketing capabilities & $\begin{array}{l}\text { Wang et al. (2008), Chang and Lee (2008), Perdomo-Ortiz et al. (2009), Lin et al. (2010), Yam } \\
\text { et al. (2011), Forsman (2011), Lin et al. (2013), Sumrit and Anuntavoranich (2013), Xiaobo and } \\
\text { Sivalogathasan (2013), Serrano García and Robledo Velásquez (2013), Kumar and Dash (2017a) }\end{array}$ \\
\hline $\begin{array}{l}\text { Robustness of product } \\
\text { and process design } \\
\text { capability }\end{array}$ & $\begin{array}{l}\text { Damanpour (1991), Lal (1992), Afuah and Bahram (1995), Panda and Ramanathan (1996), } \\
\text { Woolthuis et al. (2005), Chang and Lee (2008), Wang et al. (2008), Yam et al. (2011), Lin et al. } \\
\text { (2013), Zandhessami and Jalili (2014), De Blasio et al. (2015) }\end{array}$ \\
\hline $\begin{array}{l}\text { Innovation sourcing } \\
\text { capability }\end{array}$ & $\begin{array}{l}\text { Burgelman et al. (2004), Akman and Yilmaz (2008), Wang et al. (2008), Perdomo-Ortiz et al. } \\
\text { (2009), Xiaobo and Sivalogathasan (2013), Kumar and Dash (2017a) }\end{array}$ \\
\hline $\begin{array}{l}\text { Technology acquisition } \\
\text { capability }\end{array}$ & $\begin{array}{l}\text { Woolthuis et al. (2005), Guan et al. (2006), Chang and Lee (2008), Perdomo-Ortiz et al. (2009), } \\
\text { Lin et al. (2013), Sumrit and Anuntavoranich (2013), Xiaobo and Sivalogathasan (2013), Mor- } \\
\text { tazavi Ravari et al. (2016) }\end{array}$ \\
\hline
\end{tabular}

\subsection{Human Resources Innovation Capabilities (HRIC)}

Every business is facing challenges because of the rapid development of information technology and its impact on business. To ensure survival, holistic innovation capabilities are required for an organization. Holistic innovation capabilities must include all aspects of technology, human resources, marketing flexibility etc. In today's competitive business environment, human resources innovation capabilities are the most important capabilities to enable an organization to grow and develop. If an organization has embraced innovation capabilities in the context of HRM, that organization can survive and progress. In 1994, Wolfe talked about how the external environment was changing very quickly and suggested that every organization must focus on innovation; without innovation an organization cannot survive. He said that every organization must constantly re-visit their innovation strategy to give them an edge over their competitors.

Jackson and Schuler (1995) stated that HRM must be resourceful and ready to adopt any type of flexibilities. Lev and Zarowin (1999) found that the impact of human capabilities and skills on a firm's growth is positive and progressive. Real estate firms must focus on these skills to enhance their image among their competitors. JimenezJiménez and Sanz-Valle (2005) broke down the relationship amongst development and human asset administration (HRM) from an organisational point of view. They asked if innate development made by workers in a business was responsible for the firm's HRM or if HRM itself impacts on the development level of the organization. They investigated from both hypothetical and experimental points of view.

Jiménez-Jiménez and Sanz-Valle (2007) examined how more recent research has highlighted the significance of human asset administration, learning administration and specialized advancement as key components in gaining an edge in business. Moreover, they demonstrated a positive relationship among these three variables. This is a rare piece of work on this issue. Ling and Nasurdin (2010) concluded that, due to fast globalization, firms, especially those in the assembly sector, need to constantly adapt to remain competitive. One way to do this is by skilful human asset administration.

Leitner (2011) noted that in current literature, human capabilities and skills have both been wide- 
Table 2. Human resources innovation capabilities

\begin{tabular}{|c|c|}
\hline Criteria & Support references \\
\hline $\begin{array}{l}\text { Knowledge resources } \\
\text { capability }\end{array}$ & $\begin{array}{l}\text { Kimberly and Evanisko (1981), Grant (1996), Lev and Zarowin (1999), Young et al. (2001), Da- } \\
\text { vidsson and Honig (2003), Smith et al. (2005), Wong and He (2005), Freel (2006), Vivares et al. } \\
\text { (2016) }\end{array}$ \\
\hline $\begin{array}{l}\text { Human capital and } \\
\text { innovativeness capa- } \\
\text { bility }\end{array}$ & $\begin{array}{l}\text { Jiménez-Jiménez and Sanz-Valle (2007), Orfila-Sintes and Mattsson (2009), Ling and Nasurdin } \\
\text { (2010), Tan and Nasurdin (2011), Vaccaro et al. (2012), Volberda et al. (2013), Lusch and Namb- } \\
\text { isan (2015), Kundu and Gahlawat (2016) }\end{array}$ \\
\hline $\begin{array}{l}\text { Social capital } \\
\text { capability }\end{array}$ & $\begin{array}{l}\text { Wong and He (2005), Freel (2006), Birkinshaw et al. (2008), Tan and Nasurdin (2011), Vaccaro } \\
\text { et al. (2012), Lusch and Nambisan (2015), Vivares et al. (2016) }\end{array}$ \\
\hline $\begin{array}{l}\text { Research and devel- } \\
\text { opment cooperation } \\
\text { capability }\end{array}$ & $\begin{array}{l}\text { Lev and Zarowin (1999), Young et al. (2001), Davidsson and Honig (2003), Smith et al. (2005), } \\
\text { Wong and He (2005), Freel (2006), Tan and Nasurdin (2011), Vaccaro et al. (2012), Lusch and } \\
\text { Nambisan (2015), Akhavan and Mahdi Hosseini (2016) }\end{array}$ \\
\hline $\begin{array}{l}\text { Resource allocation } \\
\text { capability }\end{array}$ & $\begin{array}{l}\text { Grant (1996), Lev and Zarowin (1999), Young et al. (2001), Davidsson and Honig (2003), Wong } \\
\text { and He (2005), Lusch and Nambisan (2015), Kundu and Gahlawat (2016) }\end{array}$ \\
\hline Learning capability & $\begin{array}{l}\text { Lev and Zarowin (1999), Young et al. (2001), Freel (2006), Jiménez-Jiménez and Sanz-Valle } \\
\text { (2007), Ling and Nasurdin (2010), Leitner (2011), Al-bahussin and El-Garaihy (2013), Volberda } \\
\text { et al. (2013), Camisón and Villar-López (2014), Lusch and Nambisan (2015) }\end{array}$ \\
\hline
\end{tabular}

ly assessed by researchers with a positive relationship recorded. Therefore human resources and innovation must be updated according to the needs of an organization and their development plans. If necessary, some restructuring system must be implemented so that the performance and external branding of the organization is improved. Staniewski (2011) looked at the significance of human capital, noting that a competitive edge can be gained by investing in this area. In the current market, an organization may accomplish a similarly strong aggressive edge attributable to its creativity. Al-bahussin and El-Garaihy (2013) found that the areas of human asset administration, an authoritative society, information administration, hierarchical advancement and authoritative execution in the human asset administration research field are key for success. The motivation behind this study is to enrich the existing literature. The paper endeavours to explore the possible associations in the areas of an authoritative society, information administration and hierarchical innovation. The research uses causality models and recommends an applied framework resulting in a complete examination of the writing connected to the field of human asset administration.

Camisón and Villar-López (2014) evaluated the hierarchical development and mechanical advancement abilities, examining the impact on their implementation using an asset based perspective hypothetical system. Lusch and Nambisan (2015) inspected an expanded perspective of administration advancement, one grounded in an administration prevailing rationale. Nieves and Segarra-Ciprés (2015) considered how administration advancement has grown in significance as of late; however there is an absence of experimental examination dissecting the elements that support it. This paper considers two forerunners of administration development in the cordiality business. In the interior of the organization, the impact of the representatives' learning and abilities is investigated; the organization's ability to coordinate this information is also examined. In the outside setting, an assessment is carried out into how connections set up between travel industry operators and external change specialists have influenced the advancement of administration development. Various human resources innovation capabilities with their citations are shown in Table 2.

\subsection{Applications of Multi Criteria Decision Making methods in the real estate business}

Multi Criteria Decision Making (MCDM) methods have the inherent capability and potential to support the subjective evaluation of performance criteria and to make the best decisions even from the most conflicting criteria (Gudienè et al. 2014; Mortazavi Ravari et al. 2016; Kumar et al. 2017; Keshavarz Ghorabaee et al. 2018). In the real estate business, MCDM methods are employed in a variety of areas including risk investment (Bispinck 2012; Baležentis et al. 2012; Wu et al. 2012; Padhi et al. 2015; Faraji Sabokbar et al. 2016), real estate brokerage service evaluation (Ferreira et al. 2017), housing attributes (Thériault et al. 2003; Pourahmad et al. 2015), quality of life (Sabokbar et al. 2016; Kaklauskas et al. 2018), security, investor behaviour analysis (Bispinck 2012) and location (Haddad et al. 2011). However, there is no literature available on the assessment of innovation capabilities of real estate firms using MCDM 
methods. To face existing and future challenges such as strong market competition, technology advancements, demonetization and changes in consumer demand, the Indian real estate sector must think about their existing innovation capabilities. Technological and human resources innovation capabilities are fundamental to helping a business to survive and can also increase the firm's competitiveness and share of the market. With this in mind, this study has been conducted to measure the innovation capabilities of Indian real estate firms.

\section{SOLUTION METHODS}

In this section, the description of the proposed methods and those actually employed are presented. To finalize the technological innovation and human resource innovation capabilities for a real estate business, a combination of Delphi method and fuzzy set theory has been used. Even though the Delphi method helps in integrating the opinions expressed by a set of selected experts into a consensus decision-making, the ambiguity and uncertainty in their opinions still persists. In order to overcome this issue, the fuzzy Delphi method is adopted using fuzzy logic as introduced by Ishikawa et al. (1993). With the help of a fuzzy Delphi method, the experts' responses are converged by using fewer survey rounds and effectively accounting for ambiguity and uncertainty in their responses (Hanine et al. 2016; Kumar, Dash 2017b). DEMATEL is utilized to develop a network relationship map among them.

\subsection{Fuzzy set theory}

To deal with vagueness and imprecision, Zadeh (1965) developed fuzzy set theory, an extension of ordinary set theory. Following are important definitions of fuzzy set theory.

Def. 1. Assuming $U$ to be a universal set, a fuzzy set of $U$ is defined by the membership function $\mu_{A}(x) \rightarrow[0,1]$, where $\mu_{A}(x), \forall x \in U$.

Def. 2. The triangular fuzzy numbers (TFNs) of the fuzzy set are defined as follows.

$$
\mu_{A}=\left\{\begin{array}{ll}
\frac{x-p_{1}}{p_{2}-p_{1}}, & p_{1} \leq x \leq p_{2} \\
\frac{p_{3}-x}{p_{3}-p_{2}}, & p_{2} \leq x \leq p_{3} \\
0, & \text { otherwise }
\end{array}\right\} \text {, which can be de- }
$$

noted as a triplet $\left(p_{1}, p_{2}, p_{3}\right)$.
Def. 3. Suppose $\tilde{A}=\left(p_{1}, p_{2}, p_{3}\right)$ and $\tilde{B}=\left(g_{1}, g_{2}, g_{3}\right)$ are two TFNs then according to the extension principle of Zadeh (1965), the operational laws can be defined as:

1. Addition $\oplus:\left(p_{1}, p_{2}, p_{3}\right) \oplus\left(g_{1}, g_{2}, g_{3}\right)=$ $\left(p_{1}+g_{1}, p_{2}+g_{2}, p_{3}+g_{3}\right)$.

2. Subtraction $\ominus:\left(p_{1}, p_{2}, p_{3}\right) \ominus\left(g_{1}, g_{2}, g_{3}\right)=$ $\left(p_{1}-g_{1}, p_{2}-g_{2}, p_{3}-g_{3}\right)$.

3. Multiplication $\otimes:\left(p_{1}, p_{2}, p_{3}\right) \otimes\left(g_{1}, g_{2}, g_{3}\right) \cong$ $\left(p_{1} g_{1}, p_{2} g_{2}, p_{3} g_{3}\right)$.

4. Multiplication with real number $r$ : $r \otimes\left(p_{1}, p_{2}, p_{3}\right)=\left(r p_{1}, r p_{2}, r p_{3}\right)$.

5. Division $\oslash:\left(p_{1}, p_{2}, p_{3}\right) \oslash\left(g_{1}, g_{2}, g_{3}\right) \cong$ $\left(p_{1} / g_{3}, p_{2} / g_{2}, p_{3} / g_{1}\right)$.

\subsection{Fuzzy Delphi method}

To integrate expert judgment into the process aimed at identifying the evaluation capabilities, a fuzzy Delphi technique is employed. To reduce the problems of fuzzy human thoughts and low level of accuracy, triangular fuzzy numbers (TFNs) are used and capture opinions of the experts by Eq. (1). TFNs not only help us to measure vagueness and the uncertainty of information but can also be used to represent fuzzy terms in information processing:

$$
\tilde{\mathrm{W}}_{\mathrm{k}}=\left(\mathrm{a}_{\mathrm{k}}, \mathrm{b}_{\mathrm{k}}, \mathrm{c}_{\mathrm{k}}\right) \text {, }
$$

where: $\tilde{\mathrm{W}}_{\mathrm{k}}$ represents the fuzzy number for the criteria $k$ and $\mathrm{a}_{\mathrm{k}} \mathrm{b}_{\mathrm{k} \text {, }}$ and $\mathrm{c}_{\mathrm{k}}$ are the minimum, average and maximum number of expert opinion. The value of $\mathrm{S}_{\mathrm{k}}$ is calculated by Eq. (2):

$$
\mathrm{S}_{\mathrm{k}}=\left(\mathrm{a}_{\mathrm{k}}+\mathrm{b}_{\mathrm{k}}+\mathrm{c}_{\mathrm{k}}\right) / 3 \text {. }
$$

(1) If $\mathrm{S}_{\mathrm{k}} \geq \lambda$ accept criterion $k$. (2) If $\mathrm{S}_{\mathrm{k}}<\lambda$ omit criterion $k$. After finalizing the evaluation criteria, the experts have evaluated the influence of each criterion against the set of criteria; for this purpose, DEMATEL is utilized.

\subsection{DEMATEL method}

Due to the convenience of graphs for computation and optimization, the growth of graph theory in literature has been enormous (Wu 2012). This approach helps us to visualise the complex relationships among the criteria easily (Wu 2012; Kumar et al. 2017). The DEMATEL method is based on digraphs. The digraphs have the potential not only to show visual relationships among the criteria, but also to see the direction of the relationships. DEMATEL is one of the best digraphs methods (Wu, Tsai 2012; Kumar, Dash 2016). With the help of the DEMATEL method, we can visualize the inter-relationship i.e. cause-effect relationship 
among our selected capabilities. The estimation procedure for DEMATEL is explained below.

Step 1: In the first step, after identifying the final innovation capabilities, an initial relation matrix is formulated, based on the experts' judgements by asking them to score the relation from 0 -no influence to 4-high influence; the average of their opinions was calculated by using Eq. (3):

$$
\mathrm{A}=\left[a_{i j}\right]=\frac{1}{H} \sum_{K=1}^{H} x_{i j}^{k} .
$$

Step 2: Eq. (4) and Eq. (5) are used for normalization.

$$
\mathrm{F}=m \times \mathrm{A}:
$$

where: $m=\min \left[\frac{1}{\max i \sum_{i=1}^{n} a_{i j}}, \frac{1}{\max j \sum_{j=1}^{n} a_{i j}}\right]$,

$$
i, j \in\{1,2, \ldots, n\} \text {. }
$$

Step 3: Matrix (T) is identified by using Eq. (6) and Eq. (7):

$$
T=\lim _{m \rightarrow \infty}\left(F+F^{2}+\ldots+F^{m}\right)=\sum_{m=1}^{\infty} F^{i} .
$$

where: $\sum_{m=1}^{\infty} F^{i}=F^{1}+F^{2}+\ldots+F^{m}$

$$
\begin{aligned}
& =F\left(I+F^{1}+F^{2} \ldots+F^{m-1}\right) \\
& =F(I-F)^{-1}(I-F)\left(I+F^{1}+F^{2} \ldots+F^{m-1}\right) \\
& =F(I-F)^{-1}(1-F)^{m} \\
& T=F(I-F)^{-1} .
\end{aligned}
$$

Eq. (8) and Eq. (9) are used to calculate the sum of rows and columns of the matrix:

$$
\begin{aligned}
& r=\left[r_{i}\right]_{n \times 1}=\left[\sum_{j=1}^{n} t_{i j}\right]_{n \times 1} ; \\
& c=\left[c_{i}\right]_{1 \times n}=\left[\sum_{i=1}^{n} t_{i j}\right]_{1 \times n} .
\end{aligned}
$$

Step 4: To avoid minor effects, the threshold value has been calculated by using Eq. (10):

$$
\alpha=\frac{\sum_{i=1}^{n} \sum_{j=1}^{n}\left[t_{i j}\right]}{N},
$$

where: $N$ elements are in matrix T. The estimation procedure framework for fuzzy Delphi and DEMATEL is given in Figure 1.

\section{RESEARCH FRAMEWORK AND ANALYSIS}

The research framework for evaluating the technology and human resources innovation capabilities for Indian real estate firms, based on fuzzy Delphi and DEMATEL, consists of two phases. After identifying relevant capabilities through an extensive literature review, phase 1 describes how a fuzzy Delphi method has been used to finalize these capabilities after input from industry experts. Phase 2 establishes cause-effect relationships among capabilities and identifies cause group capabilities with the help of a DEMATEL method. The research framework for evaluating innovation capabilities in Indian real estate firms is shown in Figure 2.

\subsection{Phase 1: Fuzzy Delphi}

This study is based on three large Indian real estate firms - XYZ Ltd, ABC Ltd and PQR Ltd (the actual names of the firms have been made anonymous for security purposes). The contribution of these firms is huge in the Indian real estate business. Each of them aims to establish itself as the most trusted, admired and successful company in the sector. They are constantly striving to gain the trust and confidence of the public through marketing and performance. Evaluating innovation capabilities is vital for each company. Technology and human resources innovation capabilities were both examined before the construction of a network map.

To find out the major technological and human resources capabilities, the study used both qualitative and quantitative methods. The qualitative input came from a session with senior managers from real estate firms, all working in different areas. Quantitatively, a draft list of criteria was drawn up. To deal with the vagueness of information, a Delphi method with fuzzy theory has been used. TFN scales are given in Table 3. The importance of the capabilities are measured using Eq. (2).

In this study, we set a 0.6 threshold value; this is the average of the minimum value of "important" (0.5) and the maximum value of "normal" (0.7). A questionnaire is designed (in the Supplementary Appendix 1) to conduct interviews with real estate firms' experts about innovation capabilities. Table 4 and Table 5 show the importance of each capability; the final selected capabilities evaluation model is shown in Figure 3. 


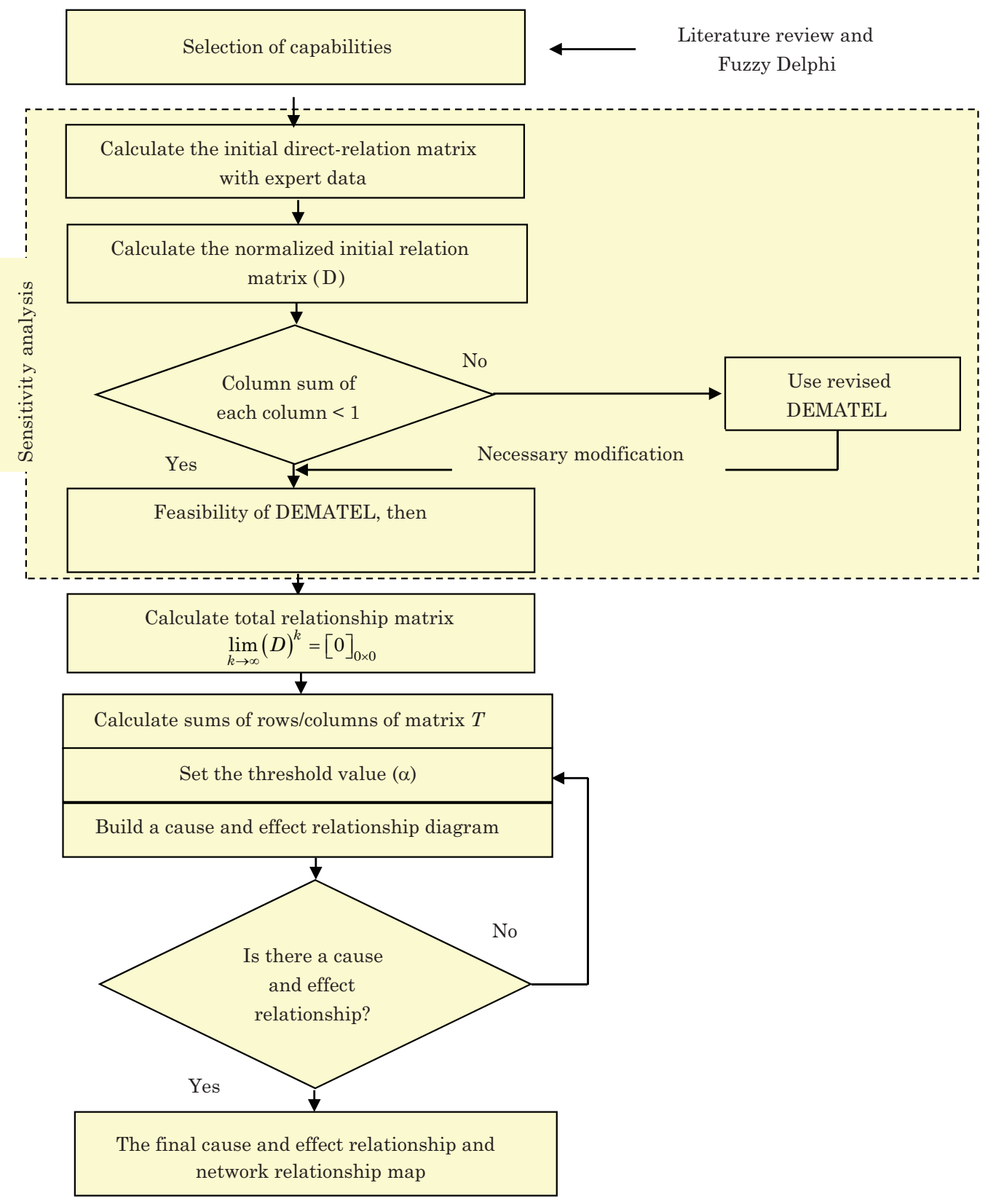

Fig. 1. Estimation procedure of fuzzy Delphi and DEMATEL

Table 3. Scales for measurement

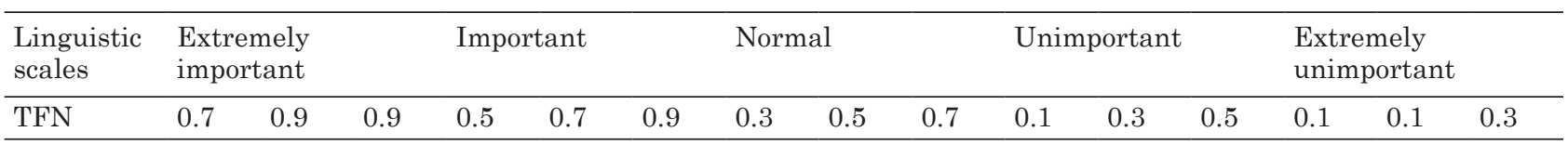

Table 4. Final criteria for technological innovation capabilities

\begin{tabular}{lll}
\hline Technological innovation capabilities & $\mathrm{S}$ & Result \\
\hline Innovation management & 0.672 & \\
Collective learning & 0.579 & cancel \\
Robustness of product and process design & 0.772 & \\
Technology commercialization & 0.689 & \\
Strategic planning capability & 0.736 & \\
Marketing capabilities & 0.543 & cancel \\
Technology acquisition capability & 0.518 & cancel \\
\hline
\end{tabular}




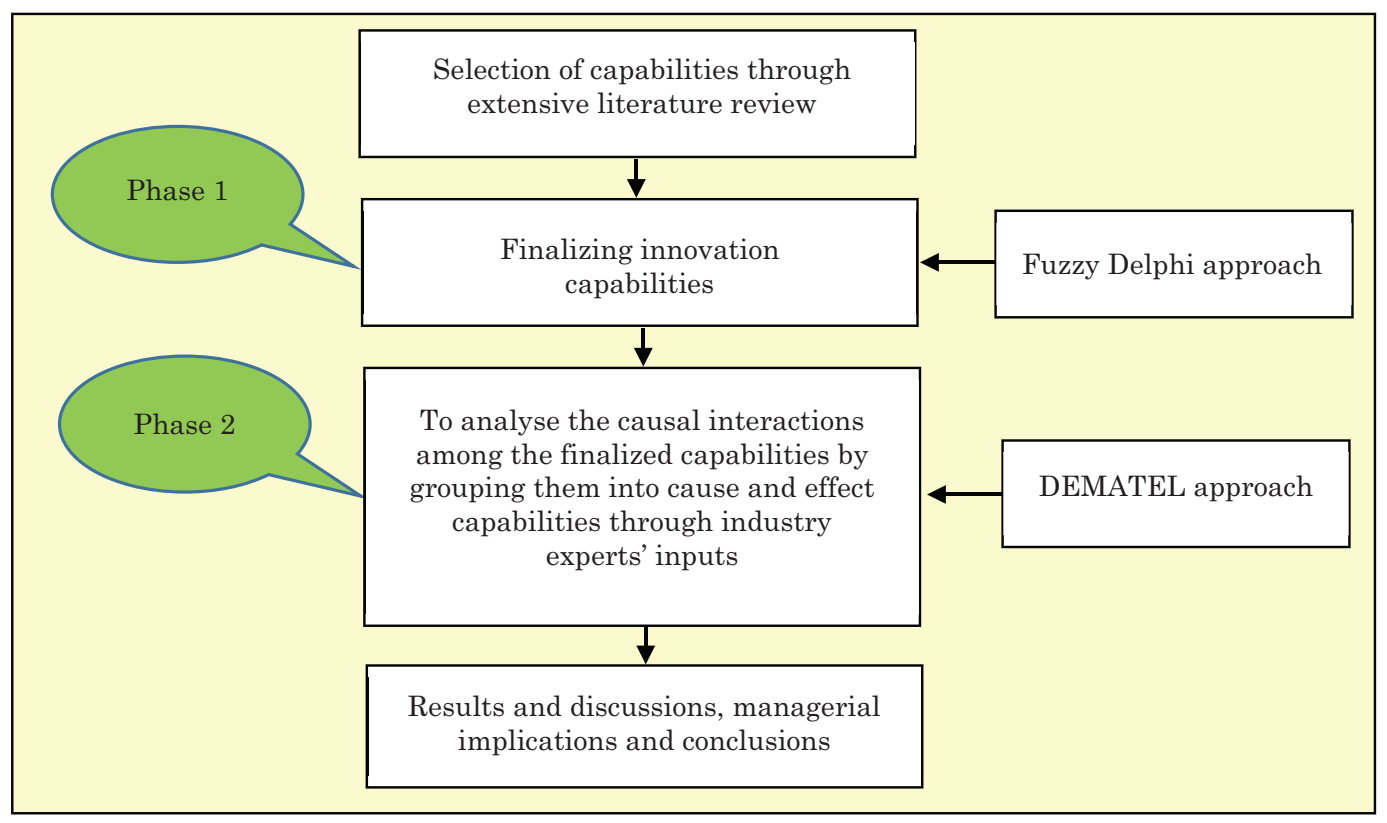

Fig. 2. Proposed research framework

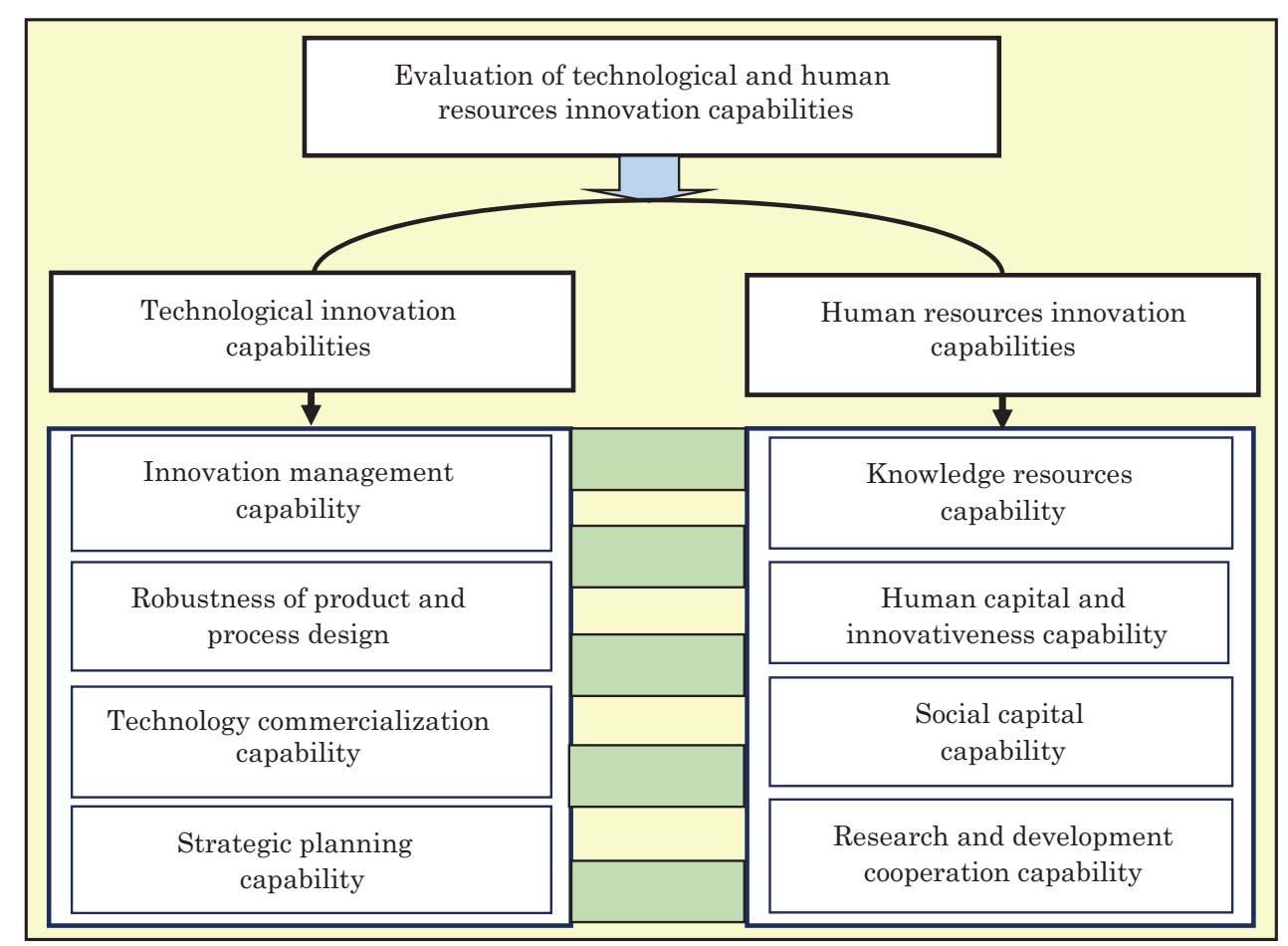

Fig. 3. Selected innovation capabilities based on Fuzzy Delphi

Table 5. Criteria for human resources innovation capabilities

\begin{tabular}{lll}
\hline Human resources innovation capabilities & S & Result \\
\hline Knowledge resources capability & 0.842 & \\
Human capital and innovativeness capability & 0.912 & \\
Social capital capability & 0.782 & \\
Resource allocation & 0.512 & cancel \\
Research and development cooperation & 0.752 & \\
Learning & 0.532 & cancel \\
\hline
\end{tabular}




\subsection{Phase 2: DEMATEL}

After finalizing the evaluation of technological and human resources innovation capabilities, a second questionnaire was developed (in the Supplementary Appendix 2); this is based on the final eight criteria for the DEMATEL method. Data has been collected by using convenience sampling and followed a rigorous process. For an effective evalu- ation, fifteen experts from different real estate firms located in the northern part of India were contacted. For each location, senior administrative managers with a minimum of 8 years working experience were invited to answer the questionnaire. Collected data is shown below in the form of $8 \times 8$ non-negative matrices with DEMATEL method computation based upon these experts' opinions.

$$
\begin{aligned}
& E^{1}=\left[\begin{array}{lllllll}
0 & 3 & 4 & 2 & 3 & 2 & 1 \\
4 & 0 & 3 & 3 & 4 & 4 & 2 \\
3 & 3 & 0 & 4 & 1 & 3 & 0 \\
3 & 1 & 4 & 0 & 2 & 3 & 3 \\
1 & 3 & 3 & 3 & 0 & 2 & 2 \\
2 & 4 & 3 & 2 & 3 & 0 & 3 \\
3 & 4 & 2 & 1 & 4 & 2 & 0
\end{array}\right], E^{2}=\left[\begin{array}{lllllll}
0 & 2 & 4 & 2 & 0 & 2 & 1 \\
4 & 0 & 4 & 2 & 1 & 2 & 2 \\
2 & 1 & 0 & 3 & 3 & 2 & 4 \\
1 & 3 & 2 & 0 & 3 & 4 & 1 \\
3 & 2 & 4 & 3 & 0 & 3 & 1 \\
2 & 2 & 3 & 2 & 1 & 0 & 2 \\
0 & 1 & 2 & 1 & 1 & 2 & 0
\end{array}\right], E^{3}=\left[\begin{array}{lllllll}
0 & 4 & 2 & 2 & 4 & 3 & 2 \\
2 & 0 & 2 & 2 & 1 & 2 & 3 \\
3 & 2 & 0 & 2 & 3 & 2 & 3 \\
4 & 2 & 2 & 0 & 3 & 4 & 2 \\
3 & 3 & 2 & 2 & 0 & 1 & 1 \\
3 & 4 & 1 & 3 & 1 & 0 & 3 \\
4 & 1 & 2 & 4 & 3 & 2 & 0
\end{array}\right], \\
& E^{4}=\left[\begin{array}{ccccccc}
0 & 2 & 1 & 4 & 2 & 4 & 2 \\
2 & 0 & 3 & 2 & 0 & 3 & 2 \\
4 & 2 & 0 & 2 & 1 & 0 & 3 \\
0 & 3 & 3 & 0 & 3 & 2 & 2 \\
1 & 2 & 2 & 3 & 0 & 2 & 2 \\
3 & 2 & 4 & 2 & 3 & 0 & 2 \\
4 & 4 & 1 & 3 & 2 & 2 & 0
\end{array}\right], E^{-}=\left[\cdots \quad E^{15}=\left[\begin{array}{ccccccc}
0 & 3 & 4 & 3 & 2 & 2 & 3 \\
2 & 0 & 2 & 4 & 3 & 3 & 4 \\
3 & 4 & 0 & 2 & 2 & 2 & 3 \\
4 & 2 & 0 & 0 & 3 & 4 & 4 \\
4 & 2 & 2 & 1 & 0 & 2 & 1 \\
3 & 1 & 4 & 3 & 2 & 0 & 3 \\
2 & 4 & 2 & 4 & 2 & 4 & 0
\end{array}\right] .\right.
\end{aligned}
$$

Step 1: By using Eq. (3), the average matrix shown in Table 6 has been formed.

Table 6. Average matrix

\begin{tabular}{llllllllll}
\hline & $\mathrm{C}_{1}$ & $\mathrm{C}_{2}$ & $\mathrm{C}_{3}$ & $\mathrm{C}_{4}$ & $\mathrm{C}_{5}$ & $\mathrm{C}_{6}$ & $\mathrm{C}_{7}$ & $\mathrm{C}_{8}$ & Sum \\
\hline $\mathrm{C}_{1}$ & 0.00 & 3.80 & 2.40 & 3.13 & 2.47 & 3.73 & 3.80 & 3.07 & 22.40 \\
$\mathrm{C}_{2}$ & 2.87 & 0.00 & 2.73 & 3.47 & 3.13 & 2.53 & 3.13 & 3.80 & 21.67 \\
$\mathrm{C}_{3}$ & 3.13 & 2.47 & 0.00 & 3.13 & 2.47 & 2.27 & 3.07 & 3.07 & 19.60 \\
$\mathrm{C}_{4}$ & 2.33 & 2.67 & 3.40 & 0.00 & 3.40 & 3.13 & 3.87 & 3.67 & 22.47 \\
$\mathrm{C}_{5}$ & 2.67 & 3.13 & 3.27 & 3.67 & 0.00 & 3.73 & 3.07 & 2.13 & 21.67 \\
$\mathrm{C}_{6}$ & 3.47 & 2.80 & 2.53 & 2.87 & 2.93 & 0.00 & 2.20 & 1.40 & 18.20 \\
$\mathrm{C}_{7}$ & 2.33 & 3.13 & 3.00 & 2.93 & 2.80 & 2.20 & 0.00 & 3.07 & 19.47 \\
$\mathrm{C}_{8}$ & 2.00 & 3.00 & 2.40 & 2.40 & 2.67 & 2.20 & 3.07 & 0.00 & 17.73 \\
\hline Sum & 18.80 & 21.00 & 19.73 & 21.60 & 19.87 & 19.80 & 22.20 & 20.20 & - \\
\hline
\end{tabular}

Step 2: Table 7 shows the nominalization of matrix $A$ calculated by $m$ x $A$; a new matrix $F$ is where:

$$
m=\min \left[\frac{1}{\max _{i} \sum_{j=1}^{n} a_{i j}}, \frac{1}{\max _{j} \sum_{j=1}^{n} a_{i j}}\right]=\left[\frac{1}{22.20}, \frac{1}{22.47}\right]=\frac{1}{22.47}=0.044 .
$$


Table 7. Norminalization matrix

\begin{tabular}{|c|c|c|c|c|c|c|c|c|c|}
\hline & & $\mathrm{C}_{1}$ & $\mathrm{C}_{2}$ & $\mathrm{C}_{3}$ & $\mathrm{C}_{4}$ & $\mathrm{C}_{5}$ & $\mathrm{C}_{6}$ & $\mathrm{C}_{7}$ & $\mathrm{C}_{8}$ \\
\hline \multirow{8}{*}{$A=$} & $\mathrm{C}_{1}$ & 0.0000 & 0.1691 & 0.1068 & 0.1395 & 0.1098 & 0.1662 & 0.1691 & 0.1365 \\
\hline & $\mathrm{C}_{2}$ & 0.1276 & 0.0000 & 0.1217 & 0.1543 & 0.1395 & 0.1128 & 0.1395 & 0.1691 \\
\hline & $\mathrm{C}_{3}$ & 0.1395 & 0.1098 & 0.0000 & 0.1395 & 0.1098 & 0.1009 & 0.1365 & 0.1365 \\
\hline & $\mathrm{C}_{4}$ & 0.1039 & 0.1187 & 0.1513 & 0.0000 & 0.1513 & 0.1395 & 0.1721 & 0.1632 \\
\hline & $\mathrm{C}_{5}$ & 0.1187 & 0.1395 & 0.1454 & 0.1632 & 0.0000 & 0.1662 & 0.1365 & 0.0950 \\
\hline & $\mathrm{C}_{6}$ & 0.1543 & 0.1246 & 0.1128 & 0.1276 & 0.1306 & 0.0000 & 0.0979 & 0.0623 \\
\hline & $\mathrm{C}_{7}$ & 0.1039 & 0.1395 & 0.1335 & 0.1306 & 0.1246 & 0.0979 & 0.0000 & 0.1365 \\
\hline & $\mathrm{C}_{8}$ & 0.0890 & 0.1335 & 0.1068 & 0.1068 & 0.1187 & 0.0979 & 0.1365 & 0.0000 \\
\hline
\end{tabular}

Table 8. Matrix T

\begin{tabular}{lllllllll}
\hline & $\mathrm{C}_{1}$ & $\mathrm{C}_{2}$ & $\mathrm{C}_{3}$ & $\mathrm{C}_{4}$ & $\mathrm{C}_{5}$ & $\mathrm{C}_{6}$ & $\mathrm{C}_{7}$ & $\mathrm{C}_{8}$ \\
\hline $\mathrm{C}_{1}$ & $\mathbf{2 . 1 3 8 6}$ & $\mathbf{1 . 4 0 3 5}$ & 1.2925 & $\mathbf{1 . 4 1 3 1}$ & 1.3029 & 1.3330 & $\mathbf{1 . 4 6 8 9}$ & 1.3436 \\
$\mathrm{C}_{2}$ & 1.2183 & $\mathbf{2 . 2 2 2 8}$ & 1.2717 & $\mathbf{1 . 3 8 8 7}$ & 1.2923 & 1.2588 & $\mathbf{1 . 4 1 0 7}$ & 1.3362 \\
$\mathrm{C}_{3}$ & 1.1357 & 1.2201 & $\mathbf{2 . 0 6 5 7}$ & 1.2722 & 1.1707 & 1.1527 & 1.3012 & 1.2116 \\
$\mathrm{C}_{4}$ & 1.2298 & $\mathbf{1 . 3 6 0 5}$ & 1.3258 & $\mathbf{2 . 2 8 7 8}$ & 1.3319 & 1.3089 & $\mathbf{1 . 4 6 8 2}$ & 1.3608 \\
$\mathrm{C}_{5}$ & 1.2178 & 1.3478 & 1.2943 & $\mathbf{1 . 4 0 0 5}$ & $\mathbf{2 . 1 7 3 8}$ & 1.3049 & $\mathbf{1 . 4 1 0 8}$ & 1.2797 \\
$\mathrm{C}_{6}$ & 1.0964 & 1.1727 & 1.1109 & 1.2040 & 1.1306 & $\mathbf{2 . 0 0 7 7}$ & 1.2081 & 1.0935 \\
$\mathrm{C}_{7}$ & 1.1010 & 1.2348 & 1.1767 & 1.2581 & 1.1755 & 1.1424 & $\mathbf{2 . 1 7 2 3}$ & 1.2044 \\
$\mathrm{C}_{8}$ & 1.0079 & 1.1408 & 1.0702 & 1.1474 & 1.0851 & 1.0571 & 1.1972 & $\mathbf{1 . 9 9 6 2}$ \\
\hline
\end{tabular}

Table 9. Final results for the capabilities

\begin{tabular}{|c|c|c|c|c|c|c|}
\hline Capability dimensions & $r_{i}$ & $c_{j}$ & $r_{i}+c_{j}$ & Rank & $r_{i}-c_{j}$ & Impact \\
\hline Innovation management $\left(\mathrm{C}_{1}\right)$ & 11.69 & 10.15 & 21.84 & 5 & 1.551 & Cause \\
\hline $\begin{array}{l}\text { Robustness of product and process } \\
\text { design capability }\left(\mathrm{C}_{2}\right)\end{array}$ & 11.40 & 11.10 & 22.50 & 1 & 0.297 & Cause \\
\hline Technology commercialization $\left(\mathrm{C}_{3}\right)$ & 10.53 & 10.61 & 21.14 & 6 & -0.078 & Effect \\
\hline Strategic planning $\left(\mathrm{C}_{4}\right)$ & 11.67 & 11.37 & 23.04 & 2 & 0.302 & Cause \\
\hline Knowledge resources $\left(\mathrm{C}_{5}\right)$ & 11.43 & 10.66 & 22.09 & 3 & 0.767 & Cause \\
\hline $\begin{array}{l}\text { Human capital \& } \\
\text { innovativeness }\left(\mathrm{C}_{6}\right)\end{array}$ & 10.02 & 10.57 & 20.59 & 7 & -0.542 & Effect \\
\hline Social capital $\left(\mathrm{C}_{7}\right)$ & 10.46 & 11.64 & 22.10 & 4 & -1.172 & Effect \\
\hline Research and development $\left(\mathrm{C}_{8}\right)$ & 9.70 & 10.83 & 20.53 & 8 & -1.124 & Effect \\
\hline
\end{tabular}

Since the sum of each column of the normalized initial direct-relation matrix in $\mathrm{A}$ is less than 1 , the feasibility solution exists and supports the applicability of DEMATEL in analysis (Lee et al. 2013; Falatoonitoosi et al. 2014).

Step 3: Using Eq. (7), matrix T is calculated as shown in Table 8.

Using Eq. (8) and Eq. (9), Table 9 is drawn up.

To avoid the minor effects in matrix $\mathrm{T}$, the threshold value $(\alpha)$ has been calculated using Eq. (10); the Network Relation Map can then be drawn up as presented in Figure 4.

$$
\alpha=\frac{\sum_{i=1}^{n} \sum_{j=1}^{n}\left[t_{i j}\right]}{N}=\frac{89.919}{64}=1.358 .
$$

All bold values in matrix $T$ are greater than the threshold value a (1.358), for example $t_{12}(1.4035)>\alpha(1.358)$. The relationship in the digraph showing a help arrow from $\mathrm{C}_{1}$ to $\mathrm{C}_{2}$ means that $\mathrm{C}_{1}$ effects $\mathrm{C}_{2}$. All relationships on the basis of threshold value and matrix $\mathrm{T}$ are constructed as shown in Figure 4 . With the help of r-c values, all selected capabilities have two groups i.e. (i) cause and (ii) effect.

(i) Where (r-c) has positive value, say net cause, these capabilities are categorised as the cause group and directly affect the others. The capability with a high value is considered to have a high impact on the other criteria directly. The analysis of this study shows that Innovation Management 


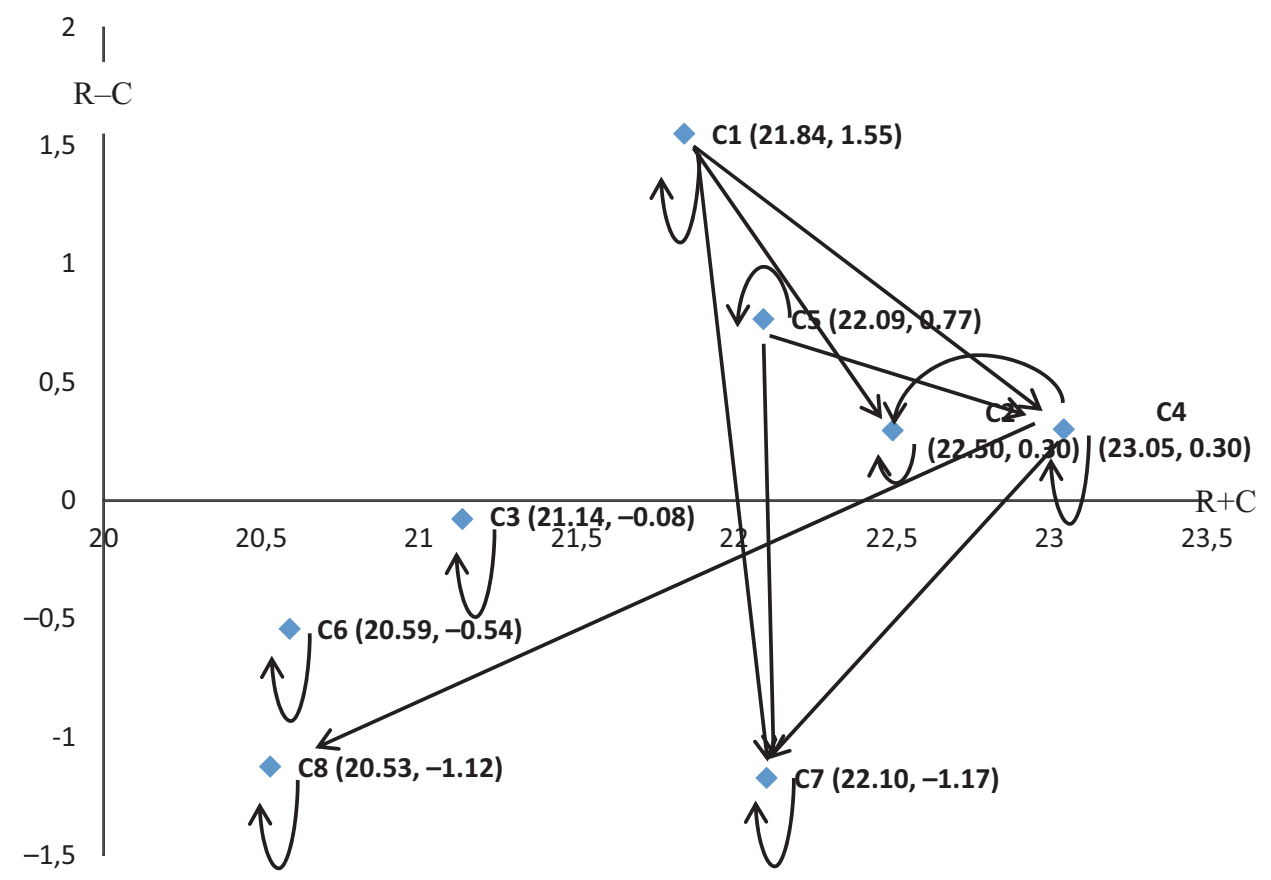

Fig. 4. Network Relation Map (NRM) within capabilities

$\left(\mathrm{C}_{1}\right)$, Robustness Product and Process Design Capability $\left(\mathrm{C}_{2}\right)$, Strategic Planning $\left(\mathrm{C}_{4}\right)$ and Knowledge Resources $\left(\mathrm{C}_{5}\right)$ are the cause group criteria with values of $r$-c of 1.551, 0.297, 0.302 and 0.767 respectively.

(ii) Those capabilities with negative values of $r$-c, all are in the effect group and are effected by the others. The analysis shows that Technology Commercialization $\left(\mathrm{C}_{3}\right)$, Human Capital \& Innovativeness $\left(\mathrm{C}_{6}\right)$, Social Capital $\left(\mathrm{C}_{7}\right)$ and Research and Development $\left(\mathrm{C}_{8}\right)$ are in the effect group with $(r-c)$ values of $-0.078,-0.542,-1.172$ and -1.124 respectively.

\section{THEORETICAL AND PRACTICAL IMPLICATIONS}

After the implementation of the Real Estate (Regulation and Development) Act 2016, followed by the demonetization declaration taken by the Indian Government, a huge change is enveloping the Indian real estate business. To cope with this constantly fluctuating environment, real estate firms must plan how to become more durable, healthier and more efficient to achieve longer, uninterrupted growth. Companies must rethink and integrate their human resources innovation capabilities (HIRCs) and technological innovation capabilities (TICs) for long term survival. These innovation capabilities have previously been regarded as an additional factor for reinforcing the competitiveness of organizations by gaining upcoming opportunities for advancement in the new market. Capabilities should now be central to forward planning for organizations.

The analysis of this study is based on Indian real estate firms and contributes much to the body of literature in both theoretical and practical perspectives. From a theoretical perspective, after identification of the technological and human resources innovation capabilities through an extensive literature review, the study used fuzzy Delphi to finalize the evaluation capabilities. To establish the inter-relationships among evaluation capabilities, DEMATEL has been used to develop a Network Relationship Map (NRM). Technological and human resources innovation should be at the heart of any business. Technological innovations and human resources can improve the prosperity of any business if plans are made from a wider perspective and have long term objectives. At an organizational level they influence individual enterprises and can ensure growth through different and difficult phases.

From a practical perspective, the study has significant practical implications for developers and investors. The results of this study can help the developer or investor to improve competitiveness and to ensure economic success. The analysis shows that the capabilities of innovation management, robustness of product and process design, strategic planning and knowledge resources are net causes 
and affect the other capabilities directly. Based on the $\mathrm{r}+\mathrm{c}$ values as given in Table 9 , the ranks of these capabilities are five, one, two and three. The capability innovation management is part of the technological innovation capabilities and it comes in the net cause group. It is directly affected by robustness of product and process design capability, strategic planning and social capital. To keep ahead of the competition, the management of a company should focus on enhancing this capability according to the time available and the demands of investors. However, this capability has rank 5 . Robustness of product and process design is part of the TICs and is affected by the same capabilities. Strategic planning is also part of TICs and is ranked 2. Management must place more emphasis on their strategic planning capability. Only knowledge resources capability is part of the human resources innovation capabilities and is ranked 4 . Management of firms should think about how to increase their knowledge resources capability to cope with today's competitive and fluctuating real estate business.

\section{CONCLUSION AND FUTURE RESEARCH DIRECTIONS}

Strengthening the firm's competitive advantages, continuous improvement in the technology innovation capabilities (TIC) and human resources innovation capabilities (HIRC) are required for all firms to be successful in the real estate business. But in existing literature, no discussion is available where evaluation of TIC and HIRC has been carried out on any real estate firm by using fuzzy Delphi and DEMATEL methods. A two-phase methodology approach is used for this study. In the initial phase, innovation capabilities related to technology innovation and human resources innovation have been identified through a literature review. To handle the vagueness of information and finalize the capabilities, the Delphi method is employed in a fuzzy environment and citation of each finalized capability is provided. After identifying the key capabilities, a second survey was conducted by employing the DEMATEL method to establish a network map showing the cause-effect relationship among the capabilities. The feasibility of solutions existing or not has been checked through the criteria given by Lee et al. (2013); this supports the applicability of a DEMATEL analysis. After employing DEMATEL, the analysis shows that innovation management, robustness of product and process design capability, strategic planning and knowledge resources are the cause group in net effect capabilities. Technology commercialization, human capital and innovativeness, social capital and research and development are effect group capabilities. The outcome of this study can help real estate firms to enhance their existing capabilities; the proposed model can provide guidelines and directions for developers who may make further studies into this field in future.

There are some limitations to this study. To handle the vagueness of information, we utilized fuzzy theory not only to finalize our capabilities but to capture any vagueness; fuzzy DEMATEL can be used for future research. Based on the cause-effect relationships among the evaluated capabilities, the hypotheses can be developed and validated in future through a larger sample.

\section{REFERENCES}

Adler, P. S.; Shenbar, A. 1990. Adapting your technological base: the organizational challenge, Sloan Management Review 32(1): 25-37.

Afuah, A. N.; Bahram, N. 1995. The hypercube of innovation, Research Policy 24(1): 51-76. https://doi.org/10.1016/0048-7333(93)00749-J

Akhavan, P.; Mahdi Hosseini, S. 2016. Social capital, knowledge sharing, and innovation capability: an empirical study of R\&D teams in Iran, Technology Analysis and Strategic Management 28(1): 96-113. https://doi.org/10.1080/09537325.2015.1072622

Akman, G.; Yilmaz, C. 2008. Innovative capability, innovation strategy and market orientation: an empirical analysis in Turkish software industry, International Journal of Innovation Management 12(1): 69-111. https://doi.org/10.1142/S1363919608001923

Al-bahussin, S. A.; El-Garaihy, W. H. 2013. The impact of human resource management practices, organisational culture, organisational innovation and knowledge management on organisational performance in large Saudi organisations: structural equation modeling with conceptual framework, International Journal of Business and Management 8(22): 1-19. https://doi.org/10.5539/ijbm.v8n22p1

Baležentis, A.; Baležentis, T.; Misiunas, A. 2012. An integrated assessment of Lithuanian economic sectors based on financial ratios and fuzzy MCDM methods, Technological and Economic Development of Economy 18(1): 34-53. https://doi.org/10.3846/20294913.2012.656151

Birkinshaw, J.; Hamel, G.; Mol, M. J. 2008. Management innovation, Academy of Management Review 33(4): 825-845. https://doi.org/10.5465/AMR.2008.34421969

Bispinck, H. 2012. Real estate investment decision making - a review, Journal of Property Investment and Finance 30(5): 529-544.

Burgelman, R. A.; Kosnik, T. J.; van der Poel, M. 1988. Toward an innovative capabilities audit framework, in Burgelman, R. A.; Maidique, A. (Eds.). Strategic 
management of technology and innovation. Irwin, Homewood, Illinois, 31-44.

Burgelman, R.; Maidique, M. A.; Wheelwright, S. C. 2004. Strategic management of technology and innovation. New York: McGraw-Hill.

Camisón, C.; Villar-López, A. 2014. Organizational innovation as an enabler of technological innovation capabilities and firm performance, Journal of Business Research 67(1): 2891-2902.

https://doi.org/10.1016/j.jbusres.2012.06.004

Chang, S. C.; Lee, M. S. 2008. The linkage between knowledge accumulation capability and organizational innovation, Journal of Knowledge Management 12(1): 3-20. https://doi.org/10.1108/13673270810852359

Cohen, W. M.; Levinthal, D. A. 1990. Absorptive capacity: a new perspective on learning and innovation, Administrative Science Quarterly 35(1): 128-152. https://doi.org/10.2307/2393553

Damanpour, F. 1991. Organizational innovation: a metaanalysis of effects of determinants and moderators, Academy of Management Journal 34(3): 555-590. https://doi.org/10.2307/256406

Davidsson, P.; Honig, B. 2003. The role of social and human capital among nascent entrepreneurs, Journal of Business Venturing 18(3): 301-331. https://doi.org/10.1016/S0883-9026(02)00097-6

De Blasio, G.; Fantino, D.; Pellegrini, G. 2015. Evaluating the impact of innovation incentives: evidence from an unexpected shortage of funds, Industrial and Corporate Change 24(6): 1285-1314. https://doi.org/10.1093/icc/dtu027

Falatoonitoosi, E.; Ahmed, S.; Sorooshian, S. 2014. Expanded DEMATEL for determining cause and effect group in bidirectional relations, The Scientific World Journal 2014, Article ID 103846. https://doi.org/10.1155/2014/103846

Faraji Sabokbar, H.; Ayashi, A.; Hosseini, A.; Banaitis, A.; Banaitienè, N.; Ayashi, R. 2016. Risk assessment in tourism system using a fuzzy set and dominance-based rough set, Technological and Economic Development of Economy 22(4): 554-573. http://dx.doi.org/10.3846/20294913.2016.1198840

Ferreira, F. A. F.; Spahr, R. W.; Sunderman, M. A.; Banaitis, A.; Ferreira, J. J. M. 2017. A learning-oriented decision-making process for real estate brokerage service evaluation, Service Business 11(3): 453-474. https://doi.org/10.1007/s11628-016-0315-4

Forsman, H. 2011. Innovation capacity and innovation development in small enterprises. A comparison between the manufacturing and service sectors, Research Policy 40(5): 739-750.

https://doi.org/10.1016/j.respol.2011.02.003

Freel, M. 2006. Patterns of technological innovation in knowledge-intensive business services, Industry and Innovation 13(3): 335-358. https://doi.org/10.1080/13662710600859157

Garcia, R.; Calantone, R. 2002. A critical look at technological innovation typology and innovativeness terminology: a literature review, Journal of Product Innovation Management 19(2): 110-132. https://doi.org/10.1016/S0737-6782(01)00132-1
Grant, R. M. 1996. Toward a knowledge-based theory of the firm, Strategic Management Journal 17(S2): 109-122. https://doi.org/10.1002/smj.4250171110

Guan, J. C.; Yam, R. C.; Mok, C. K.; Ma, N. 2006. A study of the relationship between competitiveness and technological innovation capability based on DEA models, European Journal of Operational Research 170(3): 971-986. https://doi.org/10.1016/j.ejor.2004.07.054

Guan, J.; Ma, N. 2003. Innovative capability and export performance of Chinese firms, Technovation 23(9): 737-747. https://doi.org/10.1016/S0166-4972(02)00013-5

Gudienè, N.; Banaitis, A.; Podvezko, V.; Banaitienè, N. 2014. Identification and evaluation of the critical success factors for construction projects in Lithuania: AHP approach, Journal of Civil Engineering and Management 20(3): 350-359. https://doi.org/10.3846/13923730.2014.914082

Gupta, H.; Barua, M. K. 2016. Identifying enablers of technological innovation for Indian MSMEs using best-worst multi-criteria decision making method, Technological Forecasting and Social Change 107: 69-79. https://doi.org/10.1016/j.techfore.2016.03.028

Haddad, M.; Judeh, M.; Haddad, S. 2011. Factors affecting buying behavior of an apartment an empirical investigation in Amman, Jordan, Research Journal of Applied Sciences, Engineering and Technology 3(3): 234-239.

Hanine, M.; Boutkhoum, O.; Tikniouine, A.; Agouti, T. 2016. A new web-based framework development for fuzzy multi-criteria group decision-making, SpringerPlus 5(1): 1-18. https://doi.org/10.1186/s40064-016-2198-1

Ishikawa, A.; Amagasa, M.; Shiga, T.; Tomizawa, G.; Tatsuta, R.; Mieno, H. 1993. The max-min Delphi method and fuzzy Delphi method via fuzzy integration, Fuzzy Sets and Systems 55(3): 241-253. https://doi.org/10.1016/0165-0114(93)90251-C

Jackson, S. E.; Schuler, R. S. 1995. Understanding human resource management in the context of organizations and their environments, Annual Review of Psychology 46(1): 237-264.

https://doi.org/10.1146/annurev.ps.46.020195.001321

Jimenez-Jimenez, D.; Sanz-Valle, R. 2005. Innovation and human resource management fit: an empirical study, International Journal of Manpower 26(4): 364-381. https://doi.org/10.1108/01437720510609555

Jiménez-Jiménez, D.; Sanz-Valle, R. 2007. Managing human resources in order to promote knowledge management and technical innovation, Management Research: Journal of the Iberoamerican Academy of Management 5(2): 83-100. https://doi.org/10.2753/JMR1536-5433050202

Kaklauskas, A.; Zavadskas, E. K.; Radzevičienè, A.; Ubartè, I.; Podviezko, A.; Podvezko, V.; Kuzminskè, A.; Banaitis, A.; Binkytè, A.; Bučinskas, V. 2018. Quality of city life multiple criteria analysis, Cities 72: 82-93. https://doi.org/10.1016/j.cities.2017.08.002

Keshavarz Ghorabaee, M. K.; Amiri, M.; Zavadskas, E. K.; Antucheviciene, J. 2018. A new hybrid fuzzy MCDM approach for evaluation of construction equipment 
with sustainability considerations, Archives of Civil and Mechanical Engineering 18(1): 32-49.

https://doi.org/10.1016/j.acme.2017.04.011

Kimberly, J. R.; Evanisko, M. J. 1981. Organizational innovation: the influence of individual, organizational, and contextual factors on hospital adoption of technological and administrative innovations, Academy of Management Journal 24(4): 689-713. https://doi.org/10.2307/256170

Kumar, A.; Dash, M. K. 2016. Using DEMATEL to construct influential network relation map of consumer decision-making in e-marketplace, International Journal of Business Information Systems 21(1): 4872. https://doi.org/10.1504/IJBIS.2016.073380

Kumar, A.; Dash, M. K. 2017a. Using fuzzy Delphi and generalized fuzzy TOPSIS to evaluate technological service flexibility dimensions of internet malls, Global Journal of Flexible Systems Management 18(2): 153-161. https://doi.org/10.1007/s40171-017-0154-8

Kumar, A.; Dash, M. K. 2017b. Causal modelling and analysis evaluation of online reputation management using fuzzy Delphi and DEMATEL, International Journal of Strategic Decision Sciences 8(1): 27-45. https://doi.org/10.4018/IJSDS.2017010103

Kumar, A.; Luthra, S.; Khandelwal, D. K.; Mehta, R.; Chaudhary, N.; Bhatia, S. 2017. Measuring and improving customer retention at authorised automobile workshops after free services, Journal of Retailing and Consumer Services 39: 93-102.

https://doi.org/10.1016/j.jretconser.2017.07.007

Kundu, S. C.; Gahlawat, N. 2016. Effects of employee retention practices on perceived firm and innovation performance, International Journal of Innovation and Learning 19(1): 25-43.

https://doi.org/10.1504/IJIL.2016.073287

Lall, S. 1992. Technological capabilities and industrialization, World Development 20(2): 165-186. https://doi.org/10.1016/0305-750X(92)90097-F

Lee, H.-S.; Tzeng, G.-H.; Yeih, W.; Wang, Y.-J.; Yang, S.-C. 2013. Revised DEMATEL: resolving the infeasibility of DEMATEL, Applied Mathematical Modelling 37(10-11): 6746-6757.

https://doi.org/10.1016/j.apm.2013.01.016

Leitner, K. H. 2011. The effect of intellectual capital on product innovativeness in SMEs, International Journal of Technology Management 53(1): 1-18. https://doi.org/10.1504/IJTM.2011.037235

Leonard-Barton, D. 1992. Core capabilities and core rigidities: a paradox in managing new product development, Strategic Management Journal 13(S1): 111-125. https://doi.org/10.1002/smj.4250131009

Lev, B.; Zarowin, P. 1999. The boundaries of financial reporting and how to extend them, Journal of Accounting Research 37(2): 353-385. https://doi.org/10.2307/2491413

Lin, R. J.; Chen, R. H.; Kuan-Shun Chiu, K. 2010. Customer relationship management and innovation capability: an empirical study, Industrial Management and Data Systems 110(1): 111-133. https://doi.org/10.1108/02635571011008434

Lin, Y. H.; Tseng, M. L.; Cheng, Y. L.; Chiu, A. S.; Geng, Y. 2013. Performance evaluation of technological inno- vation capabilities in uncertainty, Scientific Research and Essays 8(13): 501-514.

https://doi.org/10.5897/SRE11.1380

Ling, T. C.; Nasurdin, A. M. 2010. Human resource management practices and organizational innovation: an empirical study in Malaysia, Journal of Applied Business Research 26(4): 105-115. https://doi.org/10.19030/jabr.v26i4.311

Lusch, R. F.; Nambisan, S. 2015. Service innovation: a service-dominant logic perspective, MIS Quarterly 39(1): 155-175.

https://doi.org/10.25300/MISQ/2015/39.1.07

Mortazavi Ravari, S. S.; Mehrabanfar, E.; Banaitis, A.; Banaitienè, N. 2016. Framework for assessing technological innovation capability in research and technology organizations, Journal of Business Economics and Management 17(6): 825-847. https://doi.org/10.3846/16111699.2016.1253607

Nieves, J.; Segarra-Ciprés, M. 2015. Management innovation in the hotel industry, Tourism Management 46(2): 51-58.

https://doi.org/10.1016/j.tourman.2014.06.002

Orfila-Sintes, F.; Mattsson, J. 2009. Innovation behavior in the hotel industry, Omega 37(2): 380-394. https://doi.org/10.1016/j.omega.2007.04.002

Oyelaran-Oyeyinka, B.; Laditan, G. O. A.; Esubiyi, A. O. 1996. Industrial innovation in Sub-Saharan Africa: the manufacturing sector in Nigeria, Research Policy 25(7): 1081-1096.

https://doi.org/10.1016/S0048-7333(96)00889-X

Padhi, S. S.; Theogrosse-Ruyken, P.; Das, D. 2015. Strategic revenue management under uncertainty: a case study on real estate projects in India, Journal of Multi-Criteria Decision Analysis 22(3-4): 213-229. https://doi.org/10.1002/mcda.1537

Panda, H.; Ramanathan, K. 1996. Technological capability assessment of a firm in the electricity sector, Technovation 16(10): 561-588.

https://doi.org/10.1016/S0166-4972(97)82896-9

Perdomo-Ortiz, J.; Gonzalez-Benito, J.; Galende, J. 2009. The intervening effect of business innovation capability on the relationship between Total Quality Management and technological innovation, International Journal of Production Research 47(18): 50875107. https://doi.org/10.1080/00207540802070934

Pourahmad, A.; Hosseini, A.; Banaitis, A.; Nasiri, H.; Banaitienè, N.; Tzeng, G. H. 2015. Combination of fuzzy-AHP and DEMATEL-ANP with GIS in a new hybrid MCDM model used for the selection of the best space for leisure in a blighted urban site, Technological and Economic Development of Economy 21(5): 773-796.

https://doi.org/10.3846/20294913.2015.1056279

Sabokbar, H. F.; Hosseini, A.; Banaitis, A.; Banaitiene, N. 2016. A novel sorting method TOPSIS-sort: an application for Tehran environmental quality evaluation, E\&M Ekonomie a Management 19(2): 87-104. https://doi.org/10.15240/tul/001/2016-2-006

Serrano García, J.; Robledo Velásquez, J. 2013. Methodology for evaluating innovation capabilities at university institutions using a fuzzy system, Journal of Technology Management and Innovation 8: 246-259. https://doi.org/10.4067/S0718-27242013000300051 
Shafia, M. A.; Shavvalpour, S.; Hosseini, M.; Hosseini, R. 2016. Mediating effect of technological innovation capabilities between dynamic capabilities and competitiveness of research and technology organisations, Technology Analysis and Strategic Management 28(7): 811-826.

https://doi.org/10.1080/09537325.2016.1158404

Smith, K. G.; Collins, C. J.; Clark, K. D. 2005. Existing knowledge, creation capability and the rate of new product introduction in high-technology firms, Academy Management Journal 48(2): 346-357. https://doi.org/10.5465/AMJ.2005.16928421

Staniewski, M. W. 2011. Management of human resources in the aspect of innovativeness, Contemporary Economics 5(1): 34-52.

Sumrit, D.; Anuntavoranich, P. 2013. Using DEMATEL method to analyze the causal relations on technological innovation capability evaluation factors in Thai technology-based firms, International Transaction Journal of Engineering, Management, \& Applied Sciences \& Technologies 4(2): 81-103.

Tan, C. L.; Nasurdin, A. M. 2011. Human resource management practices and organizational innovation: assessing the mediating role of knowledge management effectiveness, Electronic Journal of Knowledge Management 9(2): 155-167.

Teece, D. J.; Pisano, G.; Shuen, A. 1997. Dynamic capabilities and strategic management, Strategic Management Journal 18(7): 509-533. https://doi. org/10.1002/(SICI)1097-0266(199708)18:7<509::AIDSMJ882>3.0.CO;2-Z

Thériault, M.; Des Rosiers, F.; Villeneuve, P.; Kestens, Y. 2003. Modelling interactions of location with specific value of housing attributes, Property Management 21(1): 25-62. https://doi.org/10.1108/02637470310464472

Vaccaro, I. G.; Jansen, J. J.; Van Den Bosch, F. A.; Volberda, H. W. 2012. Management innovation and leadership: the moderating role of organizational size, Journal of Management Studies 49(1): 28-51. https://doi.org/10.1111/j.1467-6486.2010.00976.x

Vivares, J. A.; Sarache Castro, W. A.; Naranjo-Valencia, J. C. 2016. Impact of human resource management on performance in competitive priorities, International Journal of Operations and Production Management 36(2): 114-134.

https://doi.org/10.1108/IJOPM-11-2013-0484

Volberda, H. W.; Van Den Bosch, F. A.; Heij, C. V. 2013. Management innovation: management as fertile ground for innovation, European Management Review 10(1): 1-15. https://doi.org/10.1111/emre.12007

Wang, C. H.; Lu, I. Y.; Chen, C. B. 2008. Evaluating firm technological innovation capability under uncertainty, Technovation 28(6): 349-363. https://doi.org/10.1016/j.technovation.2007.10.007

Wolfe, R. A. 1994. Organizational innovation: review, critique and suggested research directions, Journal of Management Studies 31(3): 405-431. https://doi.org/10.1111/j.1467-6486.1994.tb00624.x
Wong, P. K.; He, Z. L. 2005. A comparative study of innovation behaviour in Singapore's KIBS and manufacturing firms, Service Industries Journal 25(1): 23-42. https://doi.org/10.1080/0264206042000302397

Woolthuis, R. K.; Lankhuizen, M.; Gilsing, V. 2005. A system failure framework for innovation policy design, Technovation 25(6): 609-619. https://doi.org/10.1016/j.technovation.2003.11.002

Wu, H. H.; Tsai, Y. N. 2012. An integrated approach of AHP and DEMATEL methods in evaluating the criteria of auto spare parts industry, International Journal of Systems Science 43(11): 2114-2124. https://doi.org/10.1080/00207721.2011.564674

Wu, W. W. 2012. Segmenting critical factors for successful knowledge management implementation using the fuzzy DEMATEL method, Applied Soft Computing 12(1): 527-535. https://doi.org/10.1016/j.asoc.2011.08.008

Wu, W.; Kou, G.; Peng, Y.; Ergu, D. 2012. Improved AHP-group decision making for investment strategy selection, Technological and Economic Development of Economy 18(2): 299-316. https://doi.org/10.3846/20294913.2012.680520

Xiaobo, W. U.; Sivalogathasan, V. 2013. Innovation capability for better performance: intellectual capital and organization performance of the apparel industry in Sri Lanka, Journal of Advanced Management Science 1(3): 273-277.

Yam, R. C.; Lo, W.; Tang, E. P.; Lau, A. K. 2011. Analysis of sources of innovation, technological innovation capabilities, and performance: an empirical study of Hong Kong manufacturing industries, Research Policy 40(3): 391-402. https://doi.org/10.1016/j.respol.2010.10.013

Yang, C.; Zhang, Q.; Ding, S. 2015. An evaluation method for innovation capability based on uncertain linguistic variables, Applied Mathematics and Computation 256: 160-174. https://doi.org/10.1016/j.amc.2014.12.154

Young, G. J.; Charns, M. P.; Shortell, S. M. 2001. Top manager and network effects on the adoption of innovative management practices: a study of TQM in a public hospital system, Strategic Management Journal 22(10): 935-951. https://doi.org/10.1002/smj.194

Zadeh, L. A. 1965. Fuzzy sets, Information and Control 8(3): 338-353. https://doi.org/10.1016/S0019-9958(65)90241-X

Zandhessami, H.; Jalili, A. 2014. Causal relationship analysis based on DEMATEL technique for identifying the effect of technology innovation capability on firm competitive performance, International Journal of Management and Humanity Sciences 3(1): 12411250.

Zhao, S. L.; Song, W.; Zhu, D. Y.; Peng, X. B.; Cai, W. 2013. Evaluating China's regional collaboration innovation capability from the innovation actors perspective - An AHP and cluster analytical approach, Technology in Society 35(3): 182-190. https://doi.org/10.1016/j.techsoc.2013.06.001 